\title{
Use of capital fertiliser and lime to improve pasture production in Northland
}

\author{
M.B. O'CONNOR' and B.J. HUNT ${ }^{2}$ \\ ${ }^{1}$ AgResearch, Ruakura Agriculture Centre, Private Bag 3123, Hamilton \\ ${ }^{2}$ AgResearch, PO Box 943, Whangarei
}

\section{Abstract}

Previous research in Northland identified the requirements for phosphate and lime in pasture development. Large capital inputs were necessary (1.8-2.0 $\mathrm{t}$ superphosphate and 2.5-5 $\mathrm{t}$ lime/ha in the first 12-18 months). More recently (1990-1993) three trials have been conducted on typical unimproved or improved hill country pasture in Northland to investigate lime (rates and frequencies) and phosphate (rates and forms) requirements. Results show that capital inputs of both fertiliser and lime are still very necessary in Northland. Marked responses occurred in the trials, with an average $40 \%$ increase to $\mathrm{P}$ and $16 \%$ increase to lime. The need for a soluble fertiliser like superphosphate was highlighted. In practice the aim must be to get as much of the potentially high producing land as possible into the soil test ranges for maximising pasture production. Improvement programmes need to be tailored to the individual farm. In dairying, improvement programmes can be completed relatively quickly (1-2 years) given the current economic situation, but in hill country the programme must of necessity be longer term (4-5 years). Emphasis must first be on developing the land with the highest potential. In time, areas with lower productive potential can also be considered for improvement, although alternative sustainable land use options should also be considered.

Keywords: capital inputs, fertilisers, lime, optimum soil tests, phosphate, soil fertility

\section{Introduction}

Previous papers have emphasised the large variety of soils in Northland and the importance of fertiliser and lime in the development of pastures (During 1967; Sommerville 1967). A number of points were emphasised:

Lime and phosphate are the major inputs required for pasture development followed by potassium, sulphur, molybdenum and in some instances copper.
Large capital inputs are necessary, i.e., 1.8-2.0 t superphosphate and 2.5-5.0 t/ha lime in the first 18-24 months.

- Thereafter maintenance rates of $375 \mathrm{~kg} / \mathrm{ha} / \mathrm{annum}$ of superphosphate and 1.25 tha lime every $2-3$ years are required.

Large tracts of Northland land were developed in the 1960s and 1970s using these principles. This was followed by a period in the 1980 s which saw a general downturn in superphosphate and lime inputs (Table 1). It also was a period which saw the introduction of a MAF fertiliser advisory scheme (Cornforth \& Sinclair 1984). Unfortunately, due largely to incorrect application of the scheme many recommendations were made for low or nil fertiliser inputs. This proved to be disastrous for Northland. The 1990s saw a change of emphasis, with scientists going back to the field trial results done in Northland, summarising that data and presenting results that emphasised the difference between capital and maintenance fertiliser applications and the agronomic or biological optimum levels of nutrients for maximising pasture production (Edmeades \& O'Connor 1991; Roberts et al. 1995). More recent fertiliser recommendation schemes (e.g., Outlook ${ }^{\mathrm{TM}}$ ) use this as their basis for advice.

Table 1 Superphosphate and lime use in Northland.

\begin{tabular}{lcc}
\hline Year & Superphosphate $(t)$ & Lime $(t)$ \\
\hline 1980 & 256500 & 175000 \\
1986 & 152160 & 125800 \\
1990 & $154 \quad 220$ & NA \\
1992 & $i 66700$ & $172 \quad 000$ \\
1995 & 203500 & NA \\
\hline Source: & NZ Statistics & \\
& Farmers Fertiliser Ltd, Whangarei \\
NA: & not available & \\
\hline
\end{tabular}

The aim of this paper is to present recent trial results from Northland on phosphate and lime requirements for improving pasture production and to show how these results can be incorporated into an on-farm improvement programme. 


\section{Experimental}

Three trials were established in Northland to study phosphate and lime requirements for the development or improvement of pastures.

\section{Kamo}

This trial was established in June 1990 on an undeveloped site on the Kamo Research Area. Soil tests: $\mathrm{pH} 4.8$, Olsen $\mathrm{P} 8, \mathrm{~S} 3$, P retention 64 . Soil type: Whakapai friable clay.

Treatments included superphosphate and reactive phosphate rock (North Carolina) at 4 rates $(0,25,50$ and $100 \mathrm{~kg} \mathrm{P} / \mathrm{ha} / \mathrm{annum}) ;$ lime at rates to produce a $\mathrm{pH}$ range from 4.8-6.1 and cultivation versus oversowing. Pasture production, \% $\mathrm{P}$ and annual soil tests were measured.

\section{Waiotira-Gunson}

This trial was established in July 1991 on a farm near Waiotira (property P \& B Gunson) which had received little or no fertiliser for 8-10 years. Soil tests: $\mathrm{pH}$ 5.6, Olsen P 8, S 5, P retention 38. Soil type: Waiotira clay. Treatments included 4 phosphate fertilisers (superphosphate, reactive phosphate rock [North Carolina], Longlife Super and Parrphos $\left.18^{\mathrm{a}}\right)$ applied at 4 rates $(0$, 25,50 and $100 \mathrm{~kg} \mathrm{P} / \mathrm{ha} /$ annum) with and without lime (pH 5.6-6.3). Pasture production, $\% \mathrm{P}$ and $\mathrm{N}$ in herbage and annual soil tests were measured. An annual base dressing of elemental sulphur, gypsum, potassium and trace elements was made.

\section{Waiotira-Lovegrove}

This trial was established in June 1993 on a farm site near Waiotira (property of M. \& A. Lovegrove). Soil tests: $\mathrm{pH} 5.3$, Olsen $\mathrm{P} 10, \mathrm{~S} 5$, P retention 39. Soil type: Waiotira clay. Treatments included 8 rates of lime (0 to $9000 \mathrm{~kg} / \mathrm{ha}$ ) applied once only or annually at 4 rates $(125,250,500$ and $1000 \mathrm{~kg} / \mathrm{ha}$ ) for 3 years. Measurements were similar to Waiotira-Gunson.

\section{Results and discussion}

Lime and phosphate

Kamo

Marked responses to both lime and superphosphate were obtained in this trial. The response pattern over 3 years is shown in Figure 1. Some difficulties were encountered in reaching the required $\mathrm{pH}$ range but this

\footnotetext{
a Partially acidulated phosphate mck, Farmers Fertiliser Lrd, Whangarei. Product not commercially available.
}

Figure 1 Effect of superphosphate and lime on pasture production over 3 years at Kamo

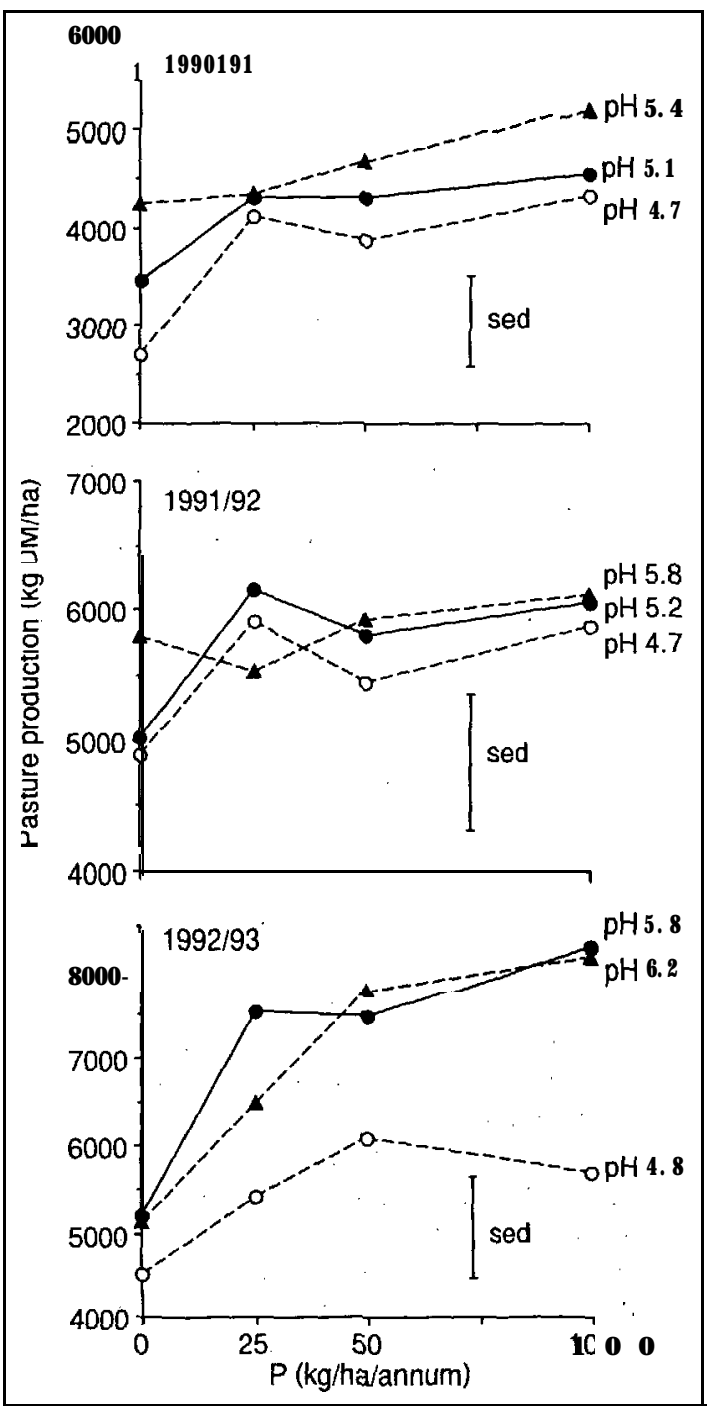

was achieved by year 3 using differential lime applications in years 1,2 and 3. The results suggest that providing $\mathrm{pH}$ is $5.8+$ near maximum pasture production is achieved at an Olsen $\mathrm{P}$ of 25-30 (data not shown). This equates to a total $\mathrm{P}$ input of approximately $200 \mathrm{~kg}$ P/ha over 3 years $(100+50+$ 50).

\section{Waiotira-Gunson}

The effect of superphosphate, in the presence and absence of lime, on pasture production over 3 years is shown in Figure 2. There was a marked lime response from an initial $\mathrm{pH}$ of 5.6. The results show that both 
Figure 2 Effect of superphospate with and without lime on pasture production over 3 years - Waiotira (Gunson).
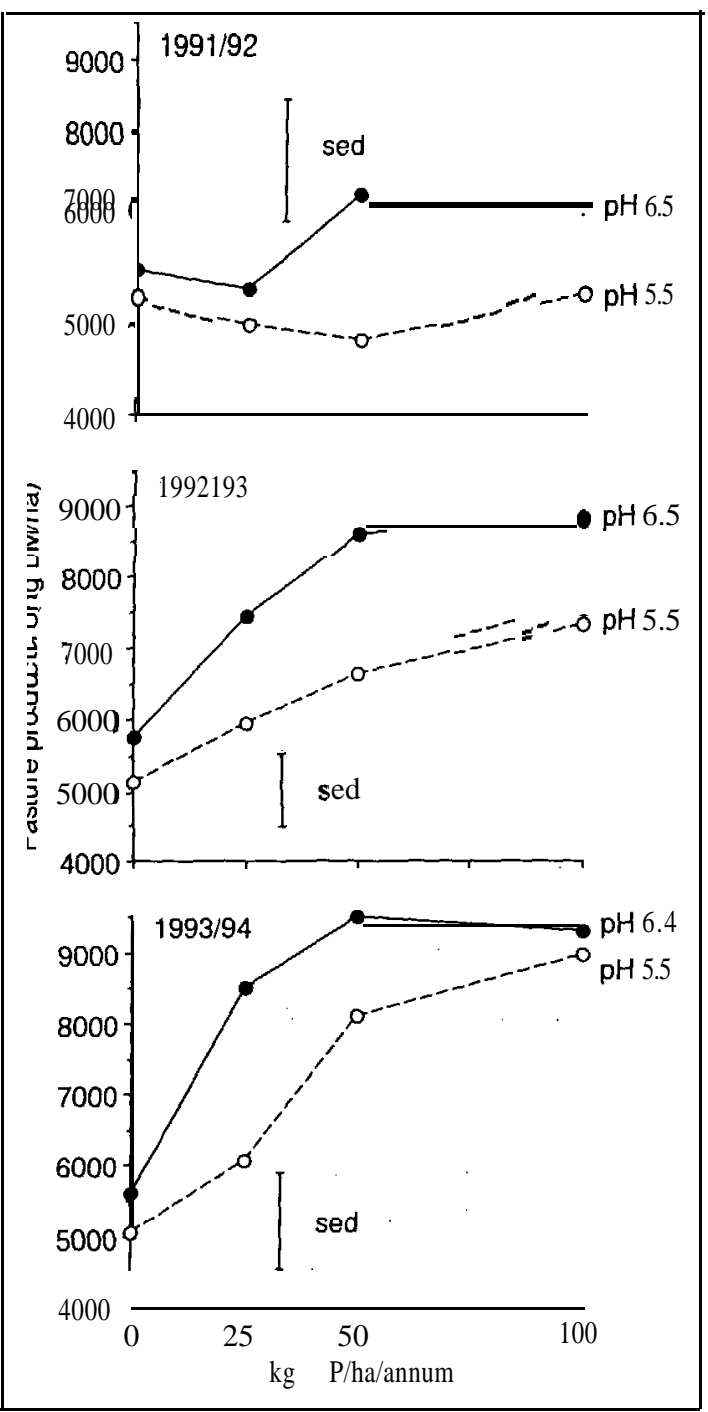

lime and superphosphate are required to maximise pasture production.

\section{Waiotira-Lovegrove}

This trial showed a marked response to lime in year 2 of the trial (Figure 3). The lack of response in the first year was attributed to a drier than normal year when rainfall was $62 \%$ of normal for the district (NZ Meteorological Service). The almost linear response to lime at this site suggests that the quicker the $\mathrm{pH}$ can be raised to an optimum level the better in terms of pasture production. $\mathrm{pH}$ changes are shown in Table 2 (year 2).
Figure 3 Effect of increasing rates of lime on pasture production - Waiotira (Lovegrove).

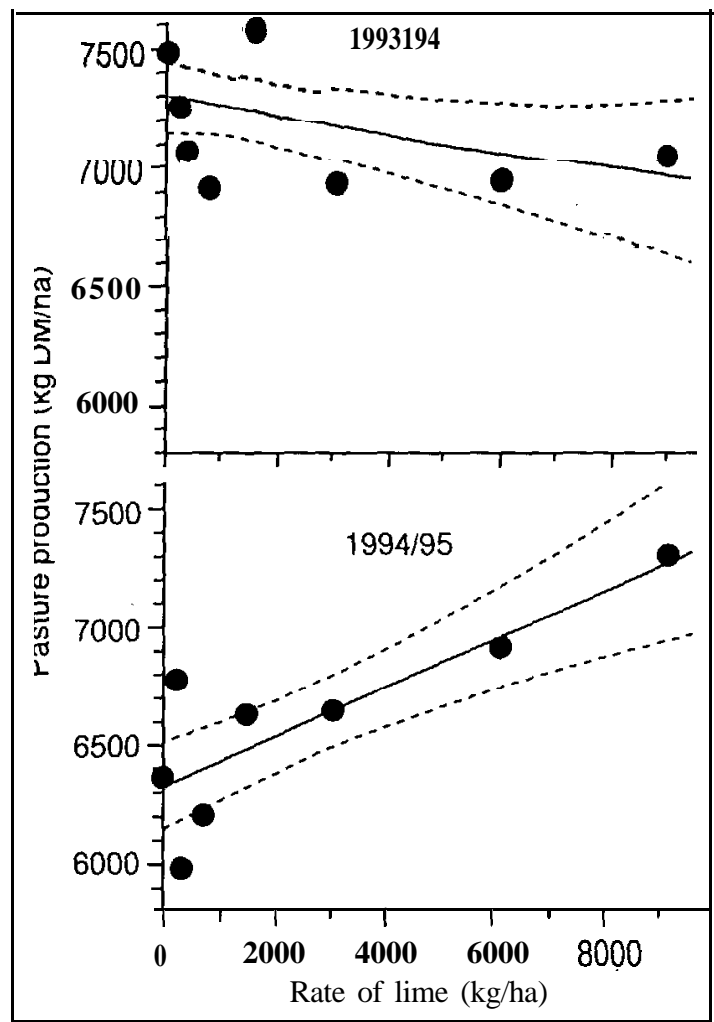

Forms of phosphate fertilisers

Both the Kamo and Waiotira-Gunson trials included, reactive phosphate rock treatments while the latter also contained mixtures of slow- and quick-release phosphate fertilisers. The pasture response to these fertilisers over 3 years is shown in the Waiotira-Gunson trial (Figure 4). Superphosphate is superior to the other products in terms of increased pasture production. Other data (not presented) shows that the increase in pasture production is consistent with the increase in $\% \mathrm{P}$ and $\mathrm{P}$ uptake.

\section{Summary of the data from the trials}

A summary of 3 years' data from the trials is shown in Table 3. The lime response is greater than the 8-1 $1 \%$ suggested by Edmeades et al. (1984) but the unit increases in $\mathrm{pH}$ and Olsen $\mathrm{P}$ are very similar to the results of other research (Edmeades et al. 1984; Roberts et al. 1995). A number of on-farm demonstration trials conducted in Northland in 1993/94 (Angus Haslett pers. comm.) also showed similar inputs of $\mathrm{P}$ were required for unit Olsen P increases, 
Figure 4 Effect of various forms ofphosphatic fertilisers (with lime) on pasture production over 3 years - Waiotira (Gunson).

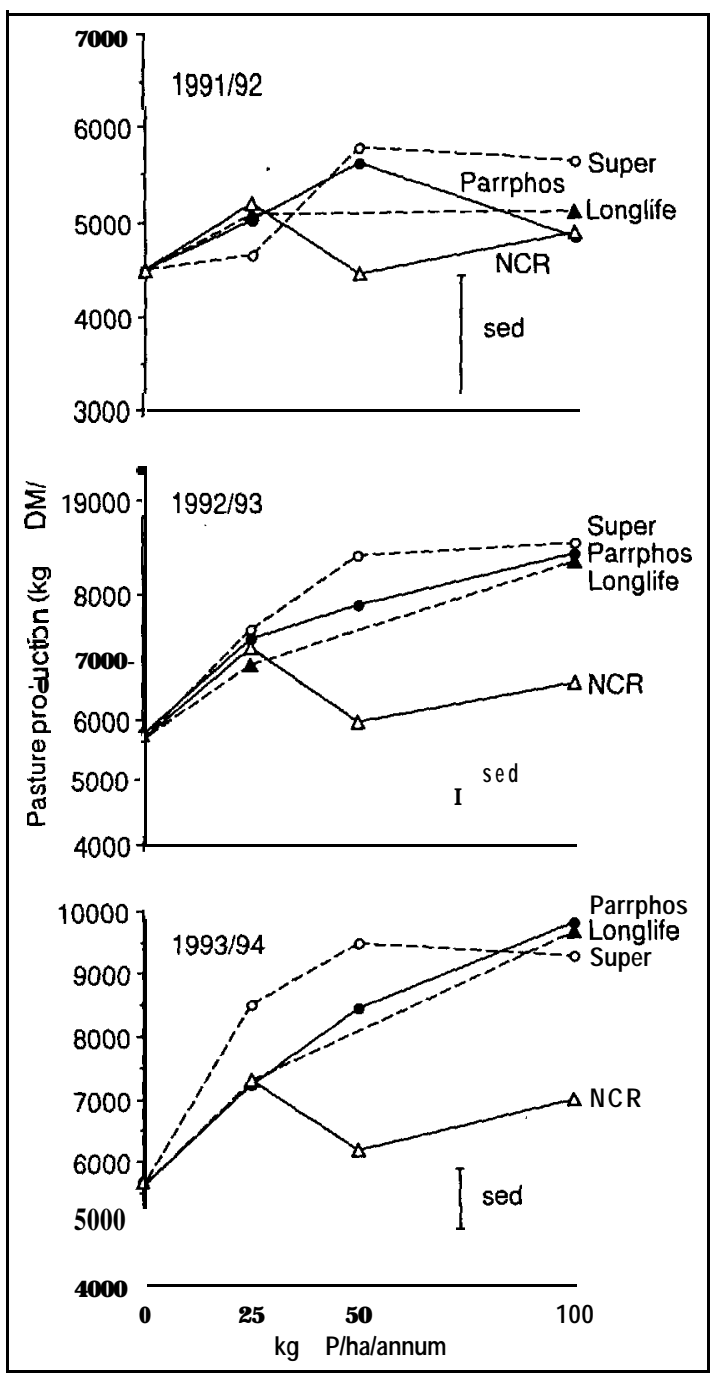

\section{On-farm improvement programmes}

\section{Dairy farms}

Soil fertility improvement programmes can be readily implemented in dairying. The economic outlook for dairying continues to look promising for that industry and any capital outlay on fertiliser should be returned quickly through increased production. Using soil tests from the farm, capital fertiliser and lime requirements can be calculated and an improvement programme implemented.
Table $2 \mathrm{pH}$ changes with the addition of lime (WaiotiraLovegrove).

\begin{tabular}{cc}
\hline Rate of lime $(\mathrm{kg} / \mathrm{ha})$ & $\mathrm{pH}$ \\
\hline 0 & 5.2 \\
250 & 5.2 \\
375 & 5.2 \\
750 & 5.3 \\
1500 & 5.4 \\
3000 & 5.6 \\
6000 & 5.8 \\
9000 & 6.3 \\
\hline
\end{tabular}

Table 3 Summary of data from 3 Northland trials.

\begin{tabular}{|c|c|c|c|}
\hline Mean & $\begin{array}{l}\text { response } \\
(\%)\end{array}$ & $\begin{array}{l}\text { Change in soil } \\
\text { test level }\end{array}$ & $\begin{array}{l}\text { Optimum } \\
\text { levels }\end{array}$ \\
\hline $\begin{array}{l}\text { Lime } \\
\text { Superphosphate }\end{array}$ & $\begin{array}{r}16 \\
40\end{array}$ & $\begin{array}{l}0.1 \mathrm{pH} \text { unit/tonne lime } \\
1 \text { Olsen } \mathrm{Punit} / 8 \mathrm{~kg} \mathrm{P}\end{array}$ & $\begin{array}{c}5.8-6.1 \\
25-30\end{array}$ \\
\hline
\end{tabular}

Hill country sheep and beef

An improvement programme for a hill country property is more complex than for a dairy farm. Let us consider a case study. The property of M. \& A. Lovegrove, Waiotira, is being used as a monitor farm and technical data are available (C. Page $\&$ R. Thomson pers. comm). An improvement programme is underway. The Outlook model (Metherell et al. 1995) is used to look at the options available and how best they can be implemented. Details of the property, soil fertility status and stocking rates are shown in Table 4.

Table 4 Waiotira hill country property (M and A Lovegrove)property details, stocking rates, soil fertility status.

\begin{tabular}{|c|c|c|c|}
\hline $\begin{array}{l}\text { Blocks } \\
\text { Contour }\end{array}$ & $\begin{array}{l}1,2,3 \\
\text { Easy }\end{array}$ & $\begin{array}{c}4,5 \\
\text { Steep }\end{array}$ & $\begin{array}{c}6 \\
\text { Flat }\end{array}$ \\
\hline $\begin{array}{l}\text { Area (ha) } \\
\text { Stockuni ts (ha) }\end{array}$ & $\begin{array}{c}270 \\
12\end{array}$ & $\begin{array}{c}231 \\
6\end{array}$ & $\begin{array}{l}19 \\
15\end{array}$ \\
\hline $\begin{array}{l}\text { Olsen P } \\
\text { pH }\end{array}$ & $\begin{array}{c}13 \\
5.5 \cdot 5.8\end{array}$ & $\begin{array}{c}7 \\
5.6\end{array}$ & $\begin{array}{r}26^{\prime} \\
5.8\end{array}$ \\
\hline Maintenance P (kg P/ha/yr) & 20 & 11 & 30 \\
\hline Maintenance Lime & \multicolumn{3}{|c|}{2.5 tha every 4 years } \\
\hline
\end{tabular}

The most economic option was found to be the one which increased production by improving the easy country at the expense of the steepland. The aim was to increase the Olsen P from 13 (Table 4) to 20 on the easy country. This could be done immediately by borrowing money to invest in capital fertiliser. A one-offapplication of $50 \mathrm{~kg} \mathrm{P} / \mathrm{ha}$ (or $150 \mathrm{t}$ superphosphate on $270 \mathrm{ha}$ ) would mean a capital outlay of $\$ 34500$. This would need an increase of $4.5 \mathrm{SU} / \mathrm{ha}$ (12 to $16.5 \mathrm{SU} / \mathrm{ha}$ ) at a 
Table 5 Waiotira hill country improvement strategy. Fertiliser inputs, fertiliser costs and expected changes in Olsen $P$ values.

\begin{tabular}{|c|c|c|c|c|c|c|c|c|}
\hline \multirow[t]{2}{*}{ Year } & \multicolumn{3}{|c|}{$\begin{array}{l}\text { Fertiliser inputs } \\
\text { (kg P/ha) }\end{array}$} & \multirow{2}{*}{\multicolumn{2}{|c|}{$\begin{array}{l}\text { Fertiliser } \\
\text { cost' }\end{array}$}} & \multicolumn{3}{|c|}{$\begin{array}{l}\text { Expected change } \\
\text { in Olsen } P\end{array}$} \\
\hline & Easy & Steep & Flat & & & Easy & Steep & Flat \\
\hline 1994 & 33 & 11 & 30 & 30600 & & 13 & 7 & 26 \\
\hline 1995 & 20 & 0 & 30 & 15250 & & 13 & 7 & 26 \\
\hline 1996 & 33 & 11 & 30 & 30600 & & 15 & 7 & 26 \\
\hline 1997 & 33 & 11 & 30 & 30 & 600 & 17 & 7 & 26 \\
\hline 1998 & 33 & 11 & 30 & 30600 & & 19 & 7 & 26 \\
\hline 1999 & 33 & 11 & 30 & 30600 & & 21 & 7 & 26 \\
\hline 2000 & 20 & 11 & 30 & 21 & 690 & 21 & 7 & 26 \\
\hline
\end{tabular}

gross margin of $\$ 28 / \mathrm{SU}$ to pay for the $\$ 34500$ outlay or over 5 years an increase of $1.2 \mathrm{SU} / \mathrm{annum}$ (18 SU in year 5$)^{b}$

An alternative and perhaps more attractive strategy for the farmer would be to have an improvement programme spread over, say, 5 years. This would involve a maintenance plus capital fertiliser input $(20+13 \mathrm{~kg}$ P/ ha/annum) applied annually for 4 years to the 'easy' blocks (note there is already l year of the programme, 1994, completed) and a maintenance or less than maintenance on the 'steep' blocks, Using this scenario, fertiliser input on the property would cost $\$ 30600$ (Table 5). Because of the expected downturn in sheep and beef farmers' incomes for 1995/96 a maintenanceonly strategy is envisaged for $1995 / 96$, with a ceiling of $\$ 15250$ for fertiliser spending (Table 5). For the following 4 years, through to 1999 , the improvement programme can be continued. However, if there is a necessity to spend less in any one year then the improvement programme can be delayed for a further year. By the year 2000 the "easy" country should be producing at near maximum production (16 SU/ha) while the "steep" country will remain in "sustainable" mode only. The small area of flat land will continue to produce at near maximum throughout. The returns from the increased stocking rate overall or improved animal performance, or both, will more than adequately pay for the outlay on additional fertiliser ( $\mathrm{S}$. Johnson pers. comm.).

\section{Conclusion}

Field trials have indicated the degree of response expected to fertiliser and lime on low-fertility Northland clay soils. Where soils are below optimum fertility for

\footnotetext{
b Interest and principal at $11 \%$ on $\$ 34,500$ would nean repaynent of $\$ 45,000$
} over5 years. near-maximum pasture production capital inputs of fertiliser and lime are required. The responses can be dramatic. An average 40\% increase in pasture production to $\mathrm{P}$ and $16 \%$ to lime have been measured in recent field trials. Field evidence also suggests a soluble P fertiliser (like superphosphate) is necessary in an improvement programme with fertiliser and lime. Slow-release type fertilisers are unsuited to capitah improvement programmes.

Correcting farm soil fertility needs a careful assessment of the production potentials of various areas and a priority setting for any improvement programme. In dairying, the improvement may be completed in 1-2 years but in hill country it could take 4-5 years and bc rather more complex. Financial constraints will limit the time needed for improvement. Input prices for fertiliser (superphosphate) at $\$ 172$ tonne are the cheapest they have been since 1985 and this needs to be considered in any improvement programme.

\section{ACKNOWLEDGEMENTS}

We are grateful for the financial support of a number of organisations in Northland in particular the Hinerangi Trust, Lime Millers Association and Farmers Fertiliser Ltd. We are also grateful for the ongoing support of a number of agricultural consultants and farmers in Northland and for the input of AgResearch staff in Whangarei and Ruakura.

I gratefully acknowledge the assistance of $\mathrm{Mr} \mathrm{S}$. Johnson of BNZ Bank, Whangarei (previously with Farmers Fertiliser Ltd, Whangarei) in the preparation of this paper.

\section{REFERENCES}

Cornforth, IS.; Sinclair, A.G. 1984. Fertiliser and lime recommendations for pastures and crops in New Zealand. Ministry of Agriculture \& Fisheries, Wellington. 76pp.

During, C. 1967. Fertilisers and lime for North Auckland soils. Proceedings NZ Grassland Association 29: 15-23.

Edmeades, D.C.; Pringle, R.M.; Shannon, P.W.; Mansell, G.P. 1984. Effects of lime on pasture production on soils in the North Island of NZ. 4. Predicting lime responses 27: 371-382.

Edmeades, D.C.; O'Connor, M.B.; Shannon, P.W.; Waller, J. 1991. Principles of soil fertility and fertiliser use in Northland. Ministry of Agriculture \& Fisheries. 12pp.

NZ Meteorological Service. Rainfall normals for NZ $1951-1980$. 
Metherell, A.K.; McCall, D.G.; Woodward, S.J.R. 1995. Outlook $^{\mathrm{TM}}$ : A phosphorus fertiliser decision support model for grazed pastures. in Fertiliser requirements of grazed pasture and field crops. Macro and Micro nutrients. Proceedings of Workshop, Massey University 24-39.

Roberts, A.H.C.; O'Connor, M.B.; Edmeades, D.C. 1995. Fertiliser use on dairy farrrs in Northland. DRC/AgResearch publication. 36pp.

Sommerville, R.K. 1967. Northland Land Development. Proceedings NZ Grassland Association 29: 24-3 1. 